\title{
BUCCAL URETEROPLASTY FOR RECURRENT EXTENDED STRICTURES AND OBLITERATIONS OF DISTAL URETER
}

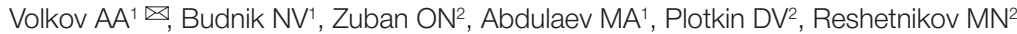

${ }^{1}$ Hospital for War Veterans, Rostov-on-Don, Russia

${ }^{2}$ Moscow Research and Clinical Center for Tuberculosis Control, Moscow, Russia

\begin{abstract}
At the current stage of development of urology, selection of the surgical method for cases of severe obstructive diseases of the upper urinary system remains a challenge. This study aimed to explore the results of application of a buccal graft (BG) to remedy extended recurrent strictures and obliterations of the distal ureter. Seven patients with the mentioned diseases had undergone surgery: for six of them, the method of choice was complete BG ureteroplasty, one had onlay ureteroplasty. One intervention was laparoscopic, the remaining surgeries were open. The length of the replaced ureteral defect was $5-8 \mathrm{~cm}$. In five cases, the flap was additionally vascularized with the iliac muscle, in one we used omentum tissue, in another - both the iliac muscle and the omentum. There were no fatalities registered, nor severe complications as per the Clavien-Dindo classification. The patients were followed-up for 4-18 months; as of today, no recurrence cases were identified. Control examinations showed complete patency of the neoureter and good vascularization of the BG. Thus, this method can be an option in cases disallowing distal ureter restoration with tissues of the patient's own urinary tract or segments of the gastrointestinal tract.
\end{abstract}

Keywords: buccal mucosa graft, ureteral obstruction, ureteral obliteration, ureteral stricture, distal ureter

Author contribution: Volkov AA, Budnik NV - study conceptualization and design development, shared responsibility, text preparation; Abdulaev MA — material collection; Volkov AA, Reshetnikov MN, Plotkin DV — statistical data processing; Volkov AA, Zuban ON — obtained data analysis; Volkov AA, Zuban ON, Reshetnikov MN — editing.

Compliance with ethical standards: the study was approved by the ethics committee of the Hospital for War Veterans (Minutes \#1 of February 6, 2018). All participants submitted the signed informed consent forms confirming their consent to participate in the study.

$\triangle$ Correspondence should be addressed: Andrey A. Volkov pereulok Zaprudny, 17, Rostov-on-Don, 344020; Volkov73a@bk.ru

Received: 25.10.2020 Accepted: 05.12.2020 Published online: 17.12.2020

DOI: 10.24075/brsmu.2020.079

\section{БУККАЛЬНАЯ УРЕТЕРОПЛАСТИКА ПРИ РЕЦИДИВНЫХ ПРОТЯЖЕННЫХ СТРИКТУРАХ И ОБЛИТЕРАЦИЯХ ДИСТАЛЬНОГО ОТДЕЛА МОЧЕТОЧНИКА}

\author{
А. А. Волков ${ }^{\otimes}$, Н. В. Будник ${ }^{1}$, О. Н. Зубань ${ }^{2}$ М. А. Абдулаев ${ }^{1}$, Д. В. Плоткин ${ }^{2}$, М. Н. Решетников ${ }^{2}$
}

${ }^{1}$ Госпиталь для ветеранов войн, Ростов-на-Дону, Россия

${ }^{2}$ Московский городской научно-практический центр борьбы с туберкулезом, Москва, Россия

\begin{abstract}
Выбор метода хирургического лечения тяжелых обструктивных заболеваний верхних мочевых путей является сложной проблемой и на современном этапе развития урологии. Целью исследования было изучить результаты применения буккального графта (БГ) при протяженных рецидивных стриктурах и облитерациях дистального отдела мочеточника. Прооперировано семь пациенток с данными заболеваниями: у шести пациенток была выполнена полная заместительная уретеропластика БГ, у одной - заместительная onlay уретеропластика. Лапароскопическим доступом оперировали в одном случае, в остальных использовали открытый. Протяженность замещенного дефекта мочеточника составила 5-8 см. Лоскут дополнительно васкуляризировали подвздошной мышцей в пяти случаях, в одном - тканью сальника, и у одной пациентки использовали подвзошную мышцу и сальник. Тяжелые осложнения по классификации Clavien-Dindo, а также летальные исходы отсутствовали. Период наблюдения за пациентами составил 4-18 месяцев, рецидива заболевания у оперированных на сегодняшний день нет. Контрольные исследования показали полную проходимость неоуретера и хорошую васкуляризацию БГ. Таким образом, данный способ может служить одной из дополнительных методик при невозможности восстановления дистального отдела мочеточника с использованием тканей собственных мочевых путей или сегментов желудочно-кишечного тракта.
\end{abstract}

Ключевые слова: буккальный графт, обструкция мочеточника, облитерация мочеточника, стриктура мочеточника, дистальный отдел мочеточника

Вклад авторов: А. А. Волков, Н. В. Будник - разработка концепции и дизайна исследования, общая ответственность, подготовка текста; М. А. Абдулаев сбор материала; А. А. Волков, М. Н. Решетников, Д. В. Плоткин - статистическая обработка данных; А. А. Волков, О. Н. Зубань - анализ полученных данных; А. А. Волков, О. Н. Зубань, М. Н. Решетников - редактирование.

Соблюдение этических стандартов: исследование одобрено этическим комитетом ГБУ «Госпиталь для ветеранов войн» (протокол № 1 от 6 февраля 2018 г.). От всех участников получено информированное согласие на включение в исследование.

$\bowtie$ Для корреспонденции: Андрей Александрович Волков пер. Запрудный, 17, г. Ростов-на-Дону. 344020; Volkov73a@bk.ru

Статья получена: 25.10.2020 Статья принята к печати: 05.12.2020 Опубликована онлайн: 17.12.2020

DOI: $10.24075 /$ vrgmu.2020.079

Extended strictures and obliterations of the ureters result from iatrogenic injuries incurred during surgeries on pelvic organs and abdominal cavity, following radiotherapy and such diseases as tuberculosis, urolithiasis, Ormond's disease, ureteral tumors, etc. [1]. There are three main groups of ureteral strictures by their origin: post-traumatic, post-inflammatory, and post-radiation [2]. Thirteen percent of patients diagnosed with iatrogenic ureter injury following urinary system surgery developed a posttraumatic stricture [3].
In most cases, obstruction of the lower third of the ureter caused by its strictures and obliterations is a result of endourological interventions aimed at urolithiasis [3-5]. Also, such obstruction may be a delayed complication of pelvic radiotherapy [6] most commonly aimed at bladder, cervix or uterine body cancer. It is a known fact that post-radiation complications in the form of urinary tract lesions may reach up to $28 \%$ in cervical cancer patients [7]. The irradiation degrades vascularization and regeneration capabilities of the subject 
Table 1. Patient group characteristics

\begin{tabular}{|c|l|c|c|}
\hline № & \multicolumn{1}{|c|}{ Diagnosis } & Etiology & Romorbidities \\
\hline 1 & Recurrent stricture of the lower third of the ureter & Endourological operations & $\begin{array}{c}\text { Bladder tumor. ICD. Essential hypertension III degree. } \\
\text { Risk 4 }\end{array}$ \\
\hline 2 & Obliteration of the lower third of the ureter & Radiation therapy & Cervical cancer \\
\hline 3 & Obliteration of the lower third of the ureter & Radiation therapy & Cervical cancer. Class 3 obesity. ICD \\
\hline 4 & Obliteration of the lower third of the ureter & Post-tuberculous ureteritis & $\begin{array}{c}\text { Spinal tuberculosis. Urinary system tuberculosis. } \\
\text { Type 2 diabetes mellitus. Class 3 obesity }\end{array}$ \\
\hline 5 & Recurrent stricture of the lower third of the ureter & Radiation therapy & Cervical cancer \\
\hline 6 & Obliteration of the lower third of the ureter & Endourological operations & ICD. Type 2 diabetes mellitus. Class 3 obesity \\
\hline 7 & Recurrent stricture of the lower third of the ureter &
\end{tabular}

tissues, which rids conservative treatment options of chances to be successful [8]. Currently, there is no distal ureter postradiation obstruction surgery method that is considered to be a standard. This type of obstruction is difficult to manage: with the ureter wall ischemia in the background, it is often impossible to use its own tissues for reconstruction purposes. Ureteroplasty variations that make use of various segments of the gastrointestinal tract entail a significant number of complications, and the success rate of such surgeries does not exceed $80 \%[9,10]$. Thus, development of the new methods for restoring patency of the distal ureter remains relevant. Most researchers believe that buccal mucosa graft (BG) shows the greatest promise in the context considered. For over 20 years now such grafts have been used as reconstruction material in surgeries remedying strictures and obliterations of the proximal and middle ureter [11].

This study aimed to explore the efficacy or using a BG to treat extended recurrent strictures and obliterations of the distal ureter.

\section{METHODS}

From 2018 to 2020, seven patients with extended strictures/ obliterations of the lower third of the ureter have undergone buccal flap replacement ureteroplasty in the surgical center of the Rostov Region Hospital for War Veterans. The mean age of the patients was $52.5+9.0$ years (36-67 years). One (14.3\%) patient was diagnosed with recurrent ureteral stricture against the background of a long-standing urolithiasis and several corrective surgical interventions; another patient (14.3\%) had recurrent post-radiation ureteral stricture after treatment of an intestinal tumor. In one case (14.3\%), the obliteration of the ureter's lower third was pronounced a result of several surgeries performed on the ureter; in three cases (42.9\%), the ureter obliteration was post-radiation by nature, an after-effect of complex treatment of cervical cancer; and in one case (14.3\%), the recurrent stricture was a consequence of the tuberculous inflammatory process.
All patients in this group had a pronounced background of comorbidities, a history of various tumor and severe systemic diseases (Table 1). In the past, patients of the analyzed group had undergone extensive surgical procedures: three (42.9\%) had malignant cervical cancer removed through extended extirpation of the uterus with appendages, which was followed by radiotherapy; three $(42.9 \%)$ had abdominal surgery, one $(14.3 \%)$ in the form of hemicolectomy targeting a malignant tumor and followed by radiotherapy, two (28.6\%) — as traditional appendectomy for destructive forms of acute appendicitis. Besides, one patient (14.3\%) had thoracolumbophrenotomy and vertebral resection for spinal tuberculosis, another (14.3\%) supravaginal uterine amputation (see Table 1).

Before buccal ureteroplasty, this group of women had undergone 21 different operations on the upper urinary system (UUS), including reconstructive, endoscopic and drainage interventions. Considering the outcomes of the said interventions, it should be noted that for almost all patients (85.3\%) they ended in persistent kidney drains, which signals of a need for alternative methods of surgical treatment. Two (28.6\%) patients were offered nephrectomy, which they refused, two more $(28.6 \%)$ had nephrostomes for more than two years.

At the time of surgery, two (28.6\%) patients already had lesions of the contralateral kidney, which led to the development of chronic kidney disease (CKD) (Table 2). In one case, blood urea was at $13.1 \mathrm{mmol} / \mathrm{l}$, blood creatinine at $259.2 \mu \mathrm{mol} / \mathrm{l}$, GFR as per the CKD-EPI formula $-18 \mathrm{ml} / \mathrm{min} / 1.73 \mathrm{~m}^{2}$. In another case, blood urea was at $11.6 \mathrm{mmol} / \mathrm{l}$, blood creatinine at $174.4 \mathrm{mmol} / \mathrm{l}$, GFR as per the CKD-EPI formula $-27 \mathrm{ml} / \mathrm{min} / 1.73 \mathrm{~m}^{2}$.

At the time of admission and at other timepoints post surgery, all patients underwent a comprehensive urological examination that included interviewing for complaints and history compilation, laboratory diagnostics, kidney ultrasonography with triplex scanning of the renal arteries, retrograde ureteropyelography, cystoscopy and ureteroscopy, computed tomography with contrast, intravenous urography, radionuclidography (as indicated), morphological studies.

Table 2. Types of previous surgical interventions

\begin{tabular}{|c|c|c|c|c|}
\hline № & Past surgeries on UUS & Contralateral kidney & CKD & Persistent drainage \\
\hline 1 & Boari operation (BO) & Norm & No & No \\
\hline 2 & $\begin{array}{c}\text { Transurethral bladder resection; ureter orifice endotomy + ureterorenoscopy } \\
\text { with contact ureterolithotripsy and ureterolithoextraction (URS) + ureter } \\
\text { stenting (US); URS + US; ureter orifice endotomy + US; URS + US; URS + } \\
\text { US; percutaneous nephrostomy (PN) }\end{array}$ & ICD. Chronic pyelonephritis & Yes & Nephrostomy \\
\hline 3 & $\mathrm{BO}, \mathrm{PN}$ & Norm & No & Nephrostomy \\
\hline 4 & $\mathrm{PN}$ & Norm & No & Nephrostomy \\
\hline 5 & PN; URS + US; IN; URS + US; BO; permanent ureter stenting & ICD. Chronic pyelonephritis & Yes & Ureteral stent \\
\hline 6 & PN & Norm & No & Nephrostomy \\
\hline 7 & URS + US; URS + US; permanent ureter stenting & Norm & No & Ureteral stent \\
\hline
\end{tabular}


Table 3. Characteristics of BG ureteroplasty in the patient group

\begin{tabular}{|c|c|c|c|c|c|}
\hline № & Type of surgery involving a BG & Method & BG length, $\mathrm{cm}$ & Additional BG vascularization & Blood loss, $\mathrm{ml}$ \\
\hline 1 & Graft onlaying onto the lower third of the ureter & Open & 5 & $\mathrm{IM}$ & 200 \\
\hline 2 & $\begin{array}{l}\text { Complete replacement of the lower third of } \\
\text { the ureter and its orifice }\end{array}$ & Open & 6 & IM & 150 \\
\hline 3 & $\begin{array}{l}\text { Complete replacement of the lower third of } \\
\text { the ureter }\end{array}$ & Open & 7 & IM & 170 \\
\hline 4 & $\begin{array}{l}\text { Complete replacement of the lower third of } \\
\text { the ureter }\end{array}$ & Open & 7 & IM & 250 \\
\hline 5 & $\begin{array}{l}\text { Complete replacement of the lower third of } \\
\text { the ureter }\end{array}$ & Open & 8 & $\mathrm{IM}+$ omentum strand & 200 \\
\hline 6 & $\begin{array}{l}\text { Complete replacement of the lower third of } \\
\text { the ureter and its orifice }\end{array}$ & Laparoscopic & 6 & Omentum strand, attached & 300 \\
\hline 7 & $\begin{array}{l}\text { Complete replacement of the lower third of } \\
\text { the ureter and its orifice }\end{array}$ & Open & 7 & IM & 200 \\
\hline
\end{tabular}

Ureteroscopy was performed with an $8 \mathrm{Ch}$ rigid ureteroscope (Karl Storz; Germany), cystoscopy - with 19-22 Ch rigid cystoscopes (Karl Storz; Germany). We used an endoscopic stand with equipment and accessories for endovideosurgery (Karl Storz; Germany), Image 1 SCONNECT, IMAGE 1S H3LINK, IMAGE 1S H3-Z, PowerLED 175 SCB, Radiance 32, ENDOFLATOR 40, HAMOUEndomat, VIO 300 D. Ultrasound examination (US) of the kidneys and their vessels was performed with Philips EPIQ 5 Elite (Philips; the Netherlands), an expert class ultrasound system; intravenous urography was performed with a TeleKoRD-MT (MTL Company; Russia), a telecontrolled X-ray diagnostic complex. Philips Brilliance 64 tomograph (Philips; the Netherlands) enabled spiral computed tomography (SCT) of the retroperitoneal space. It was done in the scanning mode, with slices $2 \mathrm{~mm}$ thick and subsequent reconstruction by $0.75 \mathrm{~mm}$ and bolus enhancement with Omnipak-300 solution (100 ml).

Six (83.3\%) patients had a buccal flap surgically placed as a complete replacement in the lower third of the ureter and its orifice, and in one (14.3\%) patient it was used as an onlay in the lower third of the ureter. Of the seven women, one (14.3\%) had the operation performed laparoscopically, and for the remaining six patients (83.7\%) the surgery was open. The length of the ureteral defect requiring replacement, as established intraoperatively, was $5-8 \mathrm{~cm}$ (median $-6.5 \mathrm{~cm}$ ) (Table 3).

Pre-surgery, the patients had their oral cavities prepared. The process included an oral cavity checkup and sanitation, a month long cigarette-free period and antiseptic mouthwash application for a week before the operation.

The presence of persistent drains and a chronic inflammatory process in the urinary system made preventive antibiotics unpromising in these patients. Post-surgery, they were prescribed long-term antibiotic therapy based on the results of bacteriological examination of urine.

In all cases, BG was additionally vascularized. For example, in five $(71.4 \%)$ of them it was attached to the iliopsoas muscle

Table 4. Surgery results
(IM). In a patient that had ureteroplasty done laparoscopically (14.3\%), the flap was wrapped with an omentum strand attached to the BG at several points; in one case (14.3\%), the vascularization was combined, it included both the $\mathrm{IM}$ and the omentum strand fixed in position.

Of the six patients with tubularized BG, three (50\%) had neoureterocystoanastomosis done following the antireflux technique (formation of a submucosal tunnel), and three more $(50 \%)$ had a direct anastomosis formed between the tubularized BG and the bladder.

In all cases, the intraoperative blood loss was minimal and did not exceed $300 \mathrm{ml}$ (see Table 3). The surgeries lasted 220-350 min (mean time - $280 \mathrm{~min}$ ).

The surgeries were considered successful if the disease did not recur within 4-18 months post-surgery and there was no need for ureteral stenting (US) or percutaneous nephrostomy (PN).

\section{RESULTS}

We continue monitoring the state of all the patients. The ureteral stent was removed routinely six weeks after surgery. The observation period for the patients is $4-18$ months. Up to this moment, none of cases presented recurrence of the disease and surgery complications. Only one (14.3\%) patient with CKD has residual hydronephrosis persisting for 11 months (Table 4).

There were no intraoperative complications registered in the analyzed group. The immediate post-surgery complications were assessed as per the Clavien-Dindo classification. It should be recognized that in this cohort of patients we did not observe severe post-surgery complications. One patient with chronic anemia needed transfusion of one dose of erythrocyte mass to correct the blood gas transport function. On the fourth day after the operation, another patient was diagnosed with an incarceration of a postoperative ventral hernia, which necessitated surgical correction under general anesthesia that was free of complications (see Table 4).

\begin{tabular}{|c|c|c|c|c|}
\hline № & Complications as per Clavien-Dindo, degree/type & Observation, months & Residual hydronephrosis & Recurrent stricture/obliteration \\
\hline 1 & No & 18 & No & No \\
\hline 2 & No & 14 & No & No \\
\hline 3 & No & 10 & No & No \\
\hline 4 & II/blood transfusion & 12 & No & No \\
\hline 5 & Illb/bowel loop incarceration & 11 & Yes & No \\
\hline 6 & No & 4 & No & No \\
\hline 7 & No & 5 & No & \\
\hline
\end{tabular}


Control studies confirmed successful engraftment of the BG in all cases: cystoscopy and ureteroscopy revealed the neoureters had pink mucous membranes and their orifices were sound. Control retrograde ureteropyelography established full patency of the anastomosis in all patients. In the first case, the CKD patients' laboratory test reports returned the following figures: blood urea - $7.8 \mathrm{mmol} / \mathrm{l}$, blood creatinine $181.4 \mu \mathrm{mol} / \mathrm{l}$, GFR as per the CKD-EPI formula $26 \mathrm{ml} / \mathrm{min} / 1.73 \mathrm{~m}^{2}$. The figures for the second case were: blood urea $-8.9 \mathrm{mmol} / \mathrm{l}$, blood creatinine $-141.6 \mu \mathrm{mol} / \mathrm{l}$, GFR as per the CKD-EPI formula - $34 \mathrm{ml} / \mathrm{min} / 1.73 \mathrm{~m}^{2}$. The figures reflect a moderate positive trend.

To date, none of the patients needs a kidney drain.

The following case reflects the degree of efficacy of buccal ureteroplasty.

Patient T., 54 years old, was admitted on 05.07.2019 to the surgical center of the Rostov Region Hospital for War Veterans for complaining about a nephrostome.

In June 2014, the patient had undergone cystoscopy for hematuria in the clinic at her place of residence. The procedure revealed villous formation at the right ureteral orifice. A transurethral resection targeting the formation followed. Histological examination revealed a benign bladder tumor. In January 2015, the patient developed lower back pain in the right side; during the examination, she was diagnosed with hydroureteronephrosis and calculi in the lower third of the right ureter. Cystoscopy revealed no right ureter orifice but a scar in its place. The procedures that followed were bougienage of right ureter orifice, cold-knife endoureterotomy, ureterorenoscopy (URS) with right side urethrolithotripsy, ureter stenting. In May 2015, URS and US were repeated. In December 2015, the disease recurred and was managed with wide cold-knife endotomy of the right ureter orifice and ureter stenting. In 2016 and 2017, the patient has undergone URS and stenting of the right ureter. In April 2019, she developed acute right-side pyelonephritis and was diagnosed with right-side hydroureteronephrosis (Fig. 1). Cystoscopy failed to reliably identify orifice of the right ureter, which was found to be impassable for the ureteral catheter (Fig. 2). The patient has undergone percutaneous nephrostomy. She was admitted to the surgical center for surgery.

Diagnosis: obliteration of the lower third of the right ureter.

On 06.07.2019, the patient had a complete replacement of the lower third of the ureter with a buccal graft.

The affected and healthy tissue interface was determined intraoperatively. The ureter, found in a conglomerate of scaraltered tissue, was resected within healthy tissues and removed along with the tissue. The next step was ligation of the ureteral stump at the site of its entry into the bladder.

The length of the removed section of the ureter was $8 \mathrm{~cm}$. The calculated length of the graft allowing anastomosis without tension was $6.5 \mathrm{~cm}$. The second team of surgeons collected a buccal mucosa graft measuring $2.2-7.0 \mathrm{~cm}$; the flap started on the right cheek's surface $(4.5 \mathrm{~cm})$ and stretched to the mucosa of the lower lip, as per the generally accepted rules. The flap was tubularized on a stent and additionally anchored to the iliopsoas muscle (IM) and bladder wall with monocryl $4 / 0$ suture material. The orifice of the neoureter was formed using the antireflux technique, with shaping of a tunnel on the superior lateral wall of the bladder.

The post-surgery period was uneventful. The backup drain was removed on the $4^{\text {th }}$ day; no urine leakage was detected. The nephrostome was removed on the $5^{\text {th }}$ day. The patient was discharged on the $7^{\text {th }}$ day in a satisfactory condition.

The stent was removed after 6 weeks. Kidney US scanning made 1, 3, 6, 9 months after the operation and excretory urography made 3 and 6 months after the operation showed regression of hydronephrosis on the right side.

A control examination performed 12 months after (kidney US scanning and SCT) revealed no right-side hydronephrosis and complete patency of the neoureter (Fig. 3). The results of the complex endourological examination were as follows: cystoscopy revealed a newly formed slit-shaped orifice that periodically let through urine (Fig. 4); retrograde ureterography showed complete patency of the replaced part of the ureter, which was moderately dilated after injection of the contrast

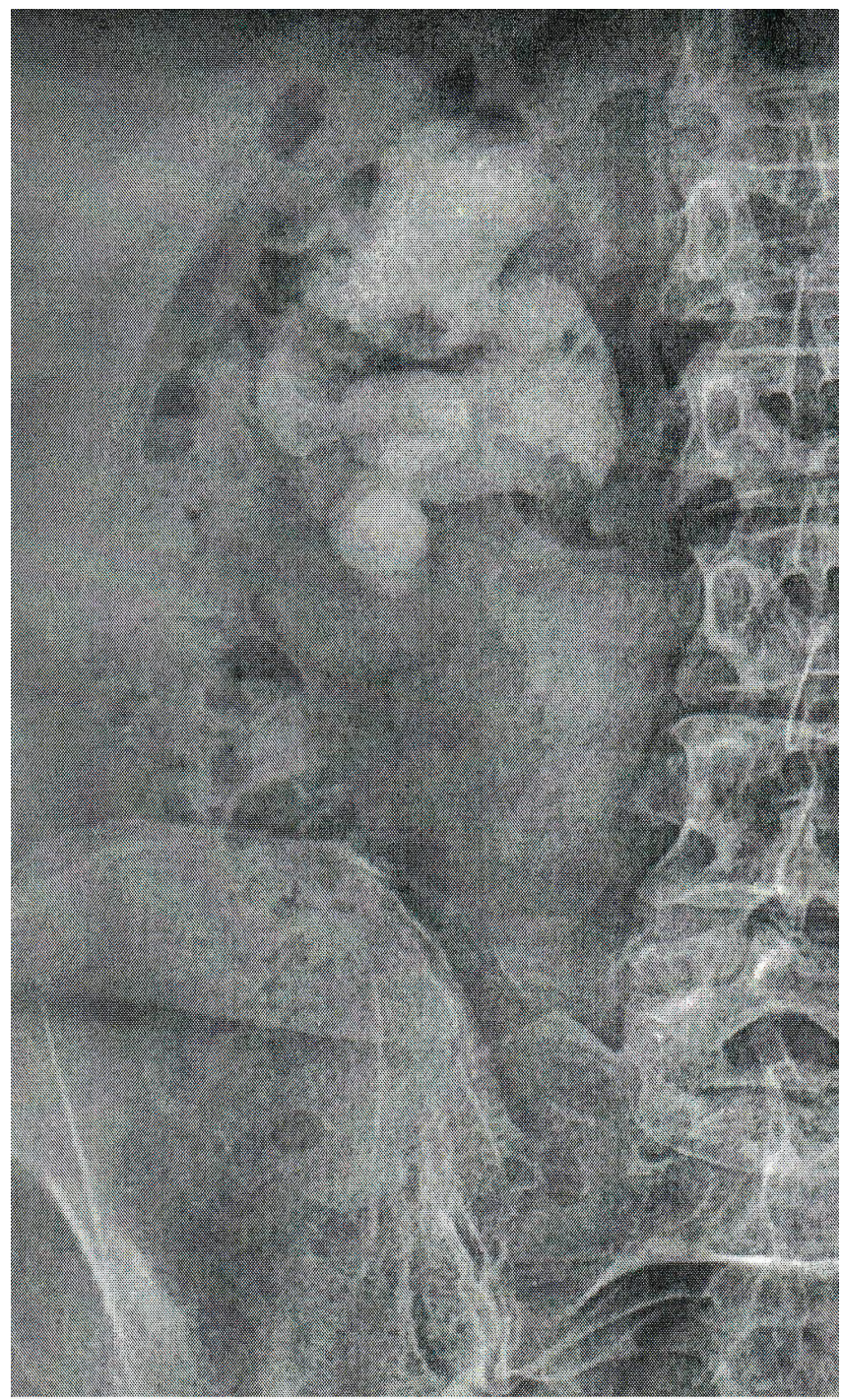

Fig. 1. Intravenous urography. Right-side hydronephrosis identified on the $60^{\text {th }}$ minute of the examination

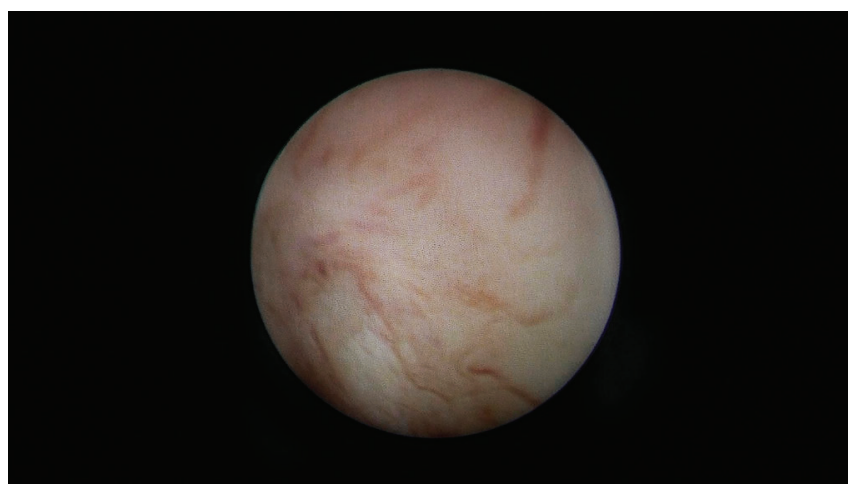

Fig. 2. Cystoscopy, pre-surgery. The orifice of the right ureter cannot be found 
agent (Fig. 5); cystography uncovered no evidence of vesicoureteral reflux; ureteroscopy showed that the neoureter's mucosa was pink, vascularization of the BG good and the lumen unobstructed (Fig. 6).

Thus, in the presented clinical case, reconstruction of the distal ureter with a BG led to a complete restoration of the kidney function and eliminated the need for persistent kidney drain.

\section{DISCUSSION}

Since 1999, when J. H. Naude used a buccal mucosa graft to reconstruct the ureter with strictures and obliterations for the first time, the number of papers dedicated to the subject has been growing steadily. Most of them describe use of a buccal flap to remedy defects in the upper third of the ureter and the pelvic-ureteric segment, i.e. in its proximal sections [12-14].

The reports covering ureter's lower third reconstruction with a BG are scarce [15-17]. According to some authors, there are standard approaches to restoration of the distal ureter in case of its obstruction, which renders application of BG for the purpose unnecessary [18]. Indeed, tissues of the patient's own UUS are considered an ideal material for restoration of patency of the system's tracts. However, the reconstructionrelated intervention options are scarce due to the limited volume of healthy tissues available, especially after past ureter inflammations and surgeries [19].

Thus, a direct ureterocystoanastomosis is a viable option only with the ureter obliterations or strictures measuring less than $5 \mathrm{~cm}$ [20]. The psoas-hitch operation, which involves mobilization of the bladder and its attachment to the psoas muscle, allows restoring UUS defects measuring up to $10 \mathrm{~cm}$, but it needs a significant strand of muscle and practically the entire lateral wall of the bladder, which can trigger a number of complications and is a challenge technically [21]. The Boari bladder flap, although effective for ureter defects up to $15 \mathrm{~cm}$ long, significantly decreases the volume of the bladder and is quite traumatic, especially when done after previous operations on the pelvic organs. Moreover, this operation is not always possible in case there are post-radiation changes in the small pelvis, when finding a well-perfused bladder flap can be a problem [22, 23].

Intestinal plastic surgery is the optimal approach for extended strictures/obliterations of the distal ureter in somatically intact patients, however, this technique entails a significant number of early and late postoperative complications, including their severe metabolic varieties, the risk of development of which is directly related to the presence of CKD, diabetes mellitus and other systemic diseases. Enteroplasty interventions imply significant intraoperative trauma; they are complicated urological operations with numerous contraindications, including concomitant radiation enteritis [24-26]. Buccal mucosa is particularly well-suited for transplantation into the urinary system: it is hairless, easily accessible for harvesting, survives well in a moist environment and has its own subepithelial vasculature that facilitates graft revascularization. Moreover, harvesting a buccal mucosa graft for urological reconstruction is associated with a low number of reported complications [27].

The use of BG minimizes bladder wall allocation, eliminates the need for traumatic mobilization of the neighboring organs from post-radiation conglomerates, allows avoiding excessive mobilization of the ureter and kidney and reduces the scale of the surgery, its duration and intraoperative blood loss. Although today it is believed that onlay ureteroplasty delivers better latestage results than ureter reconstruction with a tubularized $B G$

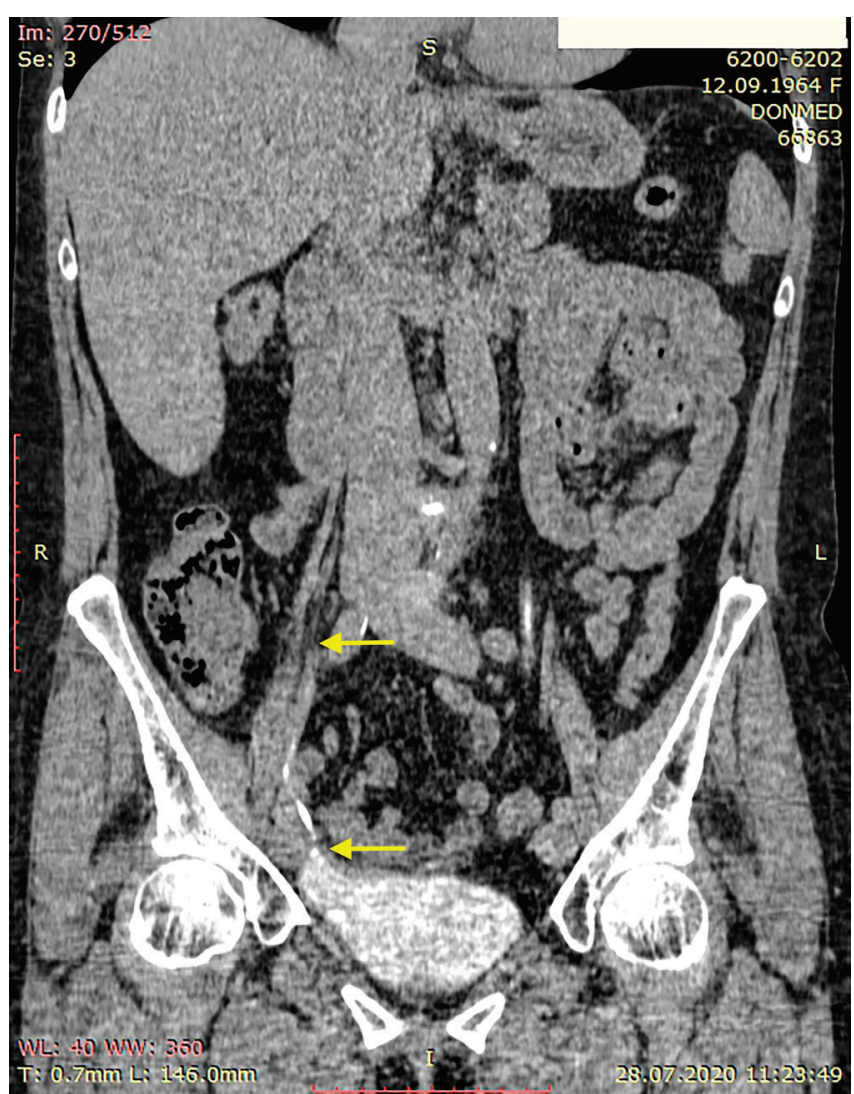

Fig. 3. Contrast enhanced computed tomography, post-surgery. Arrows mark the boundaries of the replaced ureter segment

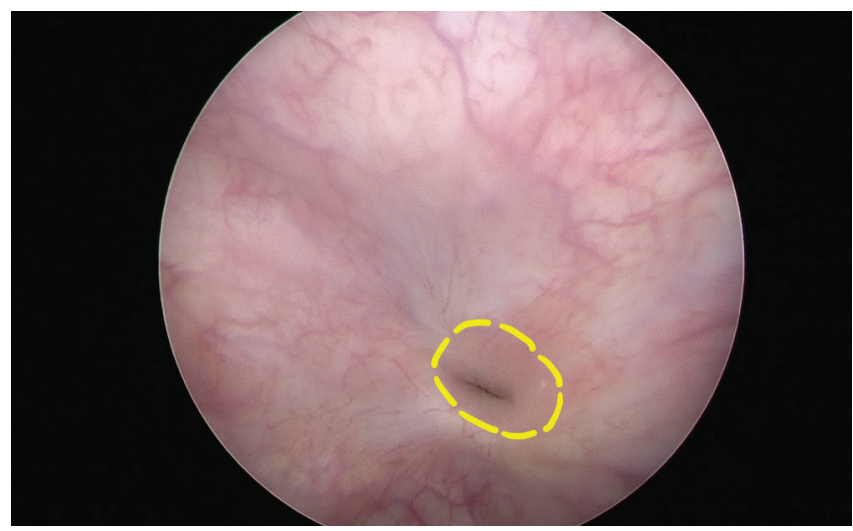

Fig. 4. Cystoscopy, post-surgery. Dotted line marks the interface between BG and mucous membrane of the bladder

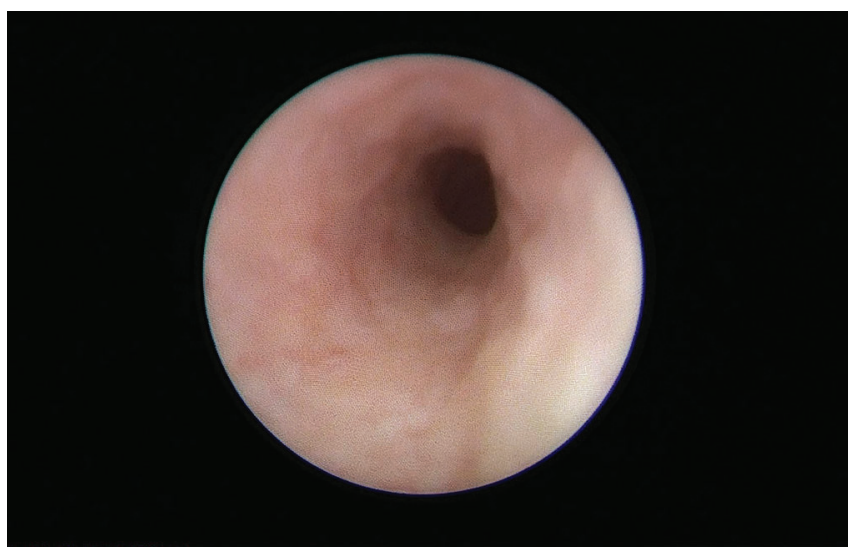

Fig. 5. Ureteroscopy, post-surgery. Visible: successful BG engraftment, wellvascularized pink mucosa 
[28], the number of reports supporting this belief is limited and disallows comparative studies.

The patients from the group considered had either extensive obliteration of the distal ureter or an extended recurrent stricture with minimal lumen. The tissues were cicatricial, with no signs of any blood circulation in them. We believe that onlaying a BG onto tissue made fibrous by prolonged specific or nonspecific inflammation, repeated surgical interventions or repeated exposure to radiation can lead to necrosis of this $B G$ and recurrence of the disease. At the same time, there is no need to isolate the entire affected part of the ureter; it is enough to prepare a section of the bladder for formation of the new orifice.

As stated in the literature, the main materials enabling vascularization of a BG are omentum flap and perinephric fat [29, 30]. In our case series, we used IS to support vascularization. It also acted as a kind of framework and feeding bed for the neoureter. Simply enveloping a tubularized BG in an omentum flap may be insufficient for neoangiogenesis. Moreover, it translates into a significant expansion of the replaced part of the ureter and can also cause circular stenosis of the implantation site due to omentum scarring [31].

\section{CONCLUSION}

The modest experience we have in using a BG to reconstruct distal ureter in patients with extended strictures and obliterations thereof shows that this technique is a viable option. In our opinion, it can be the technique of choice when using the patient's own urinary or intestinal segments is impossible or poses a high risk, which is especially relevant for patients with

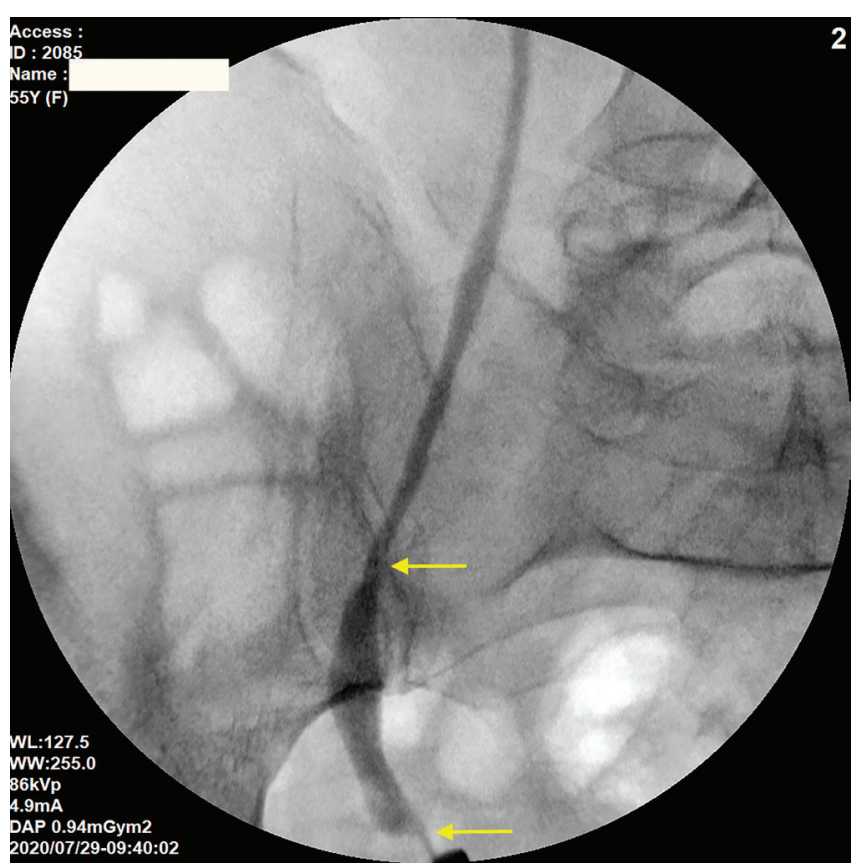

Fig. 6. Ascending ureterography, post-surgery. Arrows mark the boundaries of the replaced ureter segment

post-radiation injuries of pelvic organs. We hope that further modification of the surgical technique and analysis of long-term results registered in a significant number of patients will lead to standardization of the said technique.

\section{References}

1. Komyakov BG. Kishechnaya i appendikuljarnaja plastika mochetochnikov. M.: GJeOTAR-Media, 2015; 416 s. Russian.

2. Polyakov NV, Keshishev NG, Medvedev PE, Gurbanov ShSh, Serebryany SA, Merinov DS. Maloinvazivnye metody lechenija povrezhdenij mochetochnikov. Jeksperimental'naja i klinicheskaja urologija. 2020; 3: 132-40. DOI: 10.29188/2222-8543-2020-123-132-140. Russian.

3. Gild P, Kluth LA, Vetterlein MW, Engel O, Chun FKH, Fisch M. Adult iatrogenic ureteral injury and stricture-incidence and treatment strategies. Asian J Urol. 2018; 5 (2): 101-6. DOI: 10.1016/j. ajur.2018.02.003

4. Somani BK, Giusti G, Sun Y, Osther, PJ, Frank M, De Sio M et al. Complications associated with ureterorenoscopy (URS) related to treatment of urolithiasis: the Clinical Research Office of Endourological Society URS Global study. World J Urol. 2017; 35 (4): 675-81. DOI: 10.1007/s00345-016-1909-0.

5. D'Addessi A, Bassi P. Ureterorenoscopy: avoiding and managing the complications. Urol Int. 2011; 87 (3): 251-9. DOI: 10.1159/000329286.

6. Komyakov BK, Novikov Al, Ochelenko VA, Guliev BG, AlAttar TKh, Onoshko MV. Tehnicheskie osobennosti kishechno plastiki mochetochnikov. Chast' 6: odnovremennaja plastika mochetochnikov i mochevogo puzyrja. Urologija. 2017; 1: 12-15. DOI: 10.18565/urol.2017.1.12-15. Russian.

7. Elliott SP, Malaeb BS. Long-term urinary adverse effects of pelvic radiotherapy. World J Urol. 2011; 29 (1): 35-41. DOI: 10.1007/ s00345-010-0603-x.

8. Orchard J, Tward JD, Lenherr S, Hotaling JM, Brant WO, Myers JB. Surgical Management of Ureteral Strictures Arising From Radiotherapy for Prostate Cancer. Urol Case Rep. 2016; 6: 4749. DOI: 10.1016/j.eucr.2016.03.003.

9. Polyakov NV, Keshishev NG, Kachmazov AA, Grigorieva MV, Gurbanov SS, Kovchenko GA, i dr. Operativnoe lechenie striktur nizhnej treti mochetochnika posle luchevoj terapii organov malogo taza. Onkourologija. 2016; 12 (3): 68-73. DOI: 10.17650/17269776-2016-12-3-68-73. Russian.

10. Katibov MI, Polyakov NV, Keshishev NG, Apolikhin OI, Kaprin AD. Ispol'zovanie bukkal'nogo grafta pri strikturah mochetochnika. Urologija. 2018; 1: 138-142. DOI: 10.18565/urology. 2018.1.138142. Russian.

11. Kranz J, Brandt AS, Anheuser P, Reisch B, Steffens J, Roth S. Radiogene Harnleiterstrikturen: Mögliche Therapieoptionen [Ureteral stricture as a late complication of radiotherapy: Possible treatment options]. Urologe A. 2017; 56 (3): 322-28. DOI: 10.1007/s00120-016-0294-z.

12. Ganpule AP, Singh AG, Islam MR, Sonawane P, Sabnis RB, Desai MR. Robotic buccal mucosa graft ureteroplasty (inlay and onlay) for upper ureteric stricture: Point of technique. J Minim Access Surg. 2018; 14 (4): 357-61. DOI: 10.4103/jmas.JMAS_188_17.

13. Lee Z, Keehn AY, Sterling ME, Metro MJ, Eun DD. A Review of Buccal Mucosa Graft Ureteroplasty. Curr Urol Rep. 2018; 19 (4): 23. DOI: 10.1007/s11934-018-0772-5.

14. Volkov AA, Zuban ON, Budnik NV, Saenko GI. Ispol'zovanie kombinirovannogo bukkal'no-labial'nogo loskuta v hirurgicheskom lechenii protjazhennyh striktur i obliteracij verhnej treti i lohanochnomochetochnikovogo segmenta. Hirurg. 2019; 10: 58-67. DOI: 10.33920/med-15-1910-05. Russian.

15. Kroepfl D, Loewen $\mathrm{H}$, Klevecka $\mathrm{V}$, Musch $\mathrm{M}$. Treatment of long ureteric strictures with buccal mucosal grafts. BJU Int. 2010; 105(10): 1452-1455. DOI: 10.1111/j.1464-410X.2009.08994.x.

16. Sinelnikov LM, Protoshchak W, Karpushenko EG, Babkin PA, Barannikov MV, Kislitsyn PO, avtory; Federal'noe gosudarstvennoe bjudzhetnoe voennoe obrazovatel'noe uchrezhdenie vysshego obrazovanija "Voenno-medicinskaja akademija imeni S.M. Kirova» Ministerstva oborony Rossijskoj Federacii (VMedA), patentoobladatel'. Sposob lechenija protjazhennyh striktur tazovogo 
otdela mochetochnika s ispol'zovaniem autotransplantata iz slizistoj shheki. Patent RF \# 2712863. 01.07.2019. Russian.

17. Volkov AA, Zuban ON, Budnik NV, avtory. Volkov AA, patentoobladatel'. Sposob hirurgicheskogo lechenija recidivnyh i postluchevyh protjazhennyh striktur i obliteracij nizhnej treti mochetochnika. Patent RF \# 2709167. 11.04.2019. Russian.

18. Hefermehl LJ, Tritschler S, Kretschmer A, Beck V, Stief CG, Schlenker B, et al. Open ureteroplasty with buccal mucosa graft for long proximal strictures: A good option for a rare problem. Investig Clin Urol. 2020; 61 (3): 316-22. DOl: 10.4111/icu.2020.61.3.316.

19. Nishimura $Y$, Moriya K, Nakamura M, Kitta T, Kanno Y, Chiba H, et al. Laparoscopic ureterocalicostomy for ureteropelvic junction obstruction in a 10-year-old female patient: a case report. BMC Res Notes. 2017; 10 (1): 247. DOI: 10.1186/s13104-017-2569-X

20. Gong H, Lu Y, Yan Y, Wu Z, Gao W, Cheng H, et al. Laparoscopic Extravesical Submucosal Tunneling Ureteroneocystostomy Combined with Psoas Hitch for Medium-Length Distal Ureteral Defects in Adults. Urol Int. 2017; 98 (3): 343-49. DOI: 10.1159/000454735.

21. Manassero F, Mogorovich A, Fiorini G, Di Paola G, De Maria M, Selli C. Ureteral reimplantation with psoas bladder hitch in adults: a contemporary series with long-term followup. Scientific World Journal. 2012; 2012: 379316. DOI: 10.1100/2012/379316.

22. Castilló-Vela I, Del Pozo Jiménez G, Turo Antona J, Vázquez Alba D, Sáenz Medina J, Carballido Rodríguez J. Reimplante uretera laparoscópico con Flap de Boari [Laparoscopic Boari Flap ureteral reimplantation.]. Arch Esp Urol. 2017; 70 (4): 436-44.

23. Komyakov BK, Guliev BG. Hirurgija protjazhennyh suzhenij mochetochnikov. SPb.: Nevskij dialekt, 2005. 257 s. Russian.

24. Schott F, Becker B, Gross AJ, Netsch C. Symptomatic Distal Ureteral Stone in an lleal Ureter: Treatment by Combined Supine

\section{Литература}

1. Комяков Б. Г. Кишечная и аппендикулярная пластика мочеточников. М.: ГЭОТАР-Медиа, 2015; 416 с.

2. Поляков Н. В., Кешишев Н. Г., Медведев П. Е., Гурбанов Ш. Ш. Серебряный С. А., Меринов Д. С. Малоинвазивные методь лечения повреждений мочеточников. Экспериментальная и клиническая урология. 2020; 3: 132-40. DOI: 10.29188/22228543-2020-12-3-132-140.

3. Gild P, Kluth LA, Vetterlein MW, Engel O, Chun FKH, Fisch M. Adult iatrogenic ureteral injury and stricture-incidence and treatment strategies. Asian J Urol. 2018; 5 (2): 101-6. DOI: 10.1016/j. ajur.2018.02.003.

4. Somani BK, Giusti G, Sun Y, Osther, PJ, Frank M, De Sio M, et al. Complications associated with ureterorenoscopy (URS) related to treatment of urolithiasis: the Clinical Research Office of Endourological Society URS Global study. World J Urol. 2017; 35 (4): 675-81. DOI: 10.1007/s00345-016-1909-0.

5. D'Addessi A, Bassi P. Ureterorenoscopy: avoiding and managing the complications. Urol Int. 2011; 87 (3): 251-9. DOI: 10.1159/000329286.

6. Комяков Б. К., Новиков А. И., Очеленко В. А., Гулиев Б. Г., АлАттар Т. Х., Оношко М. В. Технические особенности кишечной пластики мочеточников. Часть 6: одновременная пластика мочеточников и мочевого пузыря. Урология. 2017; 1: 12-15. DOI: 10.18565/urol.2017.1.12-15

7. Elliott SP, Malaeb BS. Long-term urinary adverse effects of pelvic radiotherapy. World J Urol. 2011; 29 (1): 35-41. DOI: 10.1007/ s00345-010-0603-x

8. Orchard J, Tward JD, Lenherr S, Hotaling JM, Brant WO, Myers JB. Surgical Management of Ureteral Strictures Arising From Radiotherapy for Prostate Cancer. Urol Case Rep. 2016; 6: 4749. DOI: 10.1016/j.eucr.2016.03.003

9. Поляков Н. В., Кешишев Н. Г., Качмазов А. А., Григорьева М. В., Гурбанов Ш. Ш., Ковченко Г. А. и др. Оперативное лечение стриктур нижней трети мочеточника после лучевой терапии органов малого таза. Онкоурология. 2016; 12 (3): 68-73. DOI: 10.17650/1726-9776-2016-12-3-68-73.

10. Катибов М. И., Поляков Н. В., Кешишев Н. Г., Аполихин О. И.,
Ureteroscopy and Mini Percutaneous Nephrolithotomy. J Endourol Case Rep. 2017; 3 (1): 90-92. DOl: 10.1089/cren.2017.0049.

25. Kocot A, Kalogirou C, Vergho D, Riedmiller H. Long-term results of ileal ureteric replacement: a 25-year single-centre experience. BJU Int. 2017; 120 (2): 273-279. DOI: 10.1111/bju.13825.

26. Fallon B., Gaynor-Drupnick DM. Adult ureteral reconstruction. Urol Board Rev Manual. 2004; 12 (30): 2-11.

27. Tran $\mathrm{H}$, Arsovska O, Paterson RF, Chew $\mathrm{BH}$. Evaluation of risk factors and treatment options in patients with ureteral stricture disease at a single institution. Can Urol Assoc J. 2015; 9 (11-12): E921-E924. DOI: 10.5489/cuaj.3057.

28. Xiong S, Wang J, Zhu W, Yang K, Ding G, Li X, et al. Onlay Repair Technique for the Management of Ureteral Strictures: A Comprehensive Review. Biomed Res Int. 2020; 2020: 6178286. DOI: 10.1155/2020/6178286.

29. Del Pozo Jiménez G, Castillón-Vela I, Carballido Rodríguez J. Uso de injerto de mucosa oral en el tratamiento de estenosis ureterales extensas: revisión de conjunto [Buccal mucosa graft for the treatment of long ureteral stenosis: Bibliographic review.]. Arch Esp Urol. 2017; 70 (4): 445-53.

30. Fahmy O, Schubert T, Khairul-Asri MG, Stenzl A, Gakis G. Total proximal ureter substitution using buccal mucosa. Int J Urol. 2017; 24 (4): 320-23. DOI: 10.1111/iju.13307.

31. Paronnikov MV, Shestaev AYu, Karpushchenko EG, Sinelnikov LM, Protoshak W, Yantsev AA, avtory; Federal'noe gosudarstvennoe bjudzhetnoe voennoe obrazovatel'noe uchrezhdenie vysshego obrazovanija «Voenno-medicinskaja akademija imeni S.M. Kirova» Ministerstva oborony Rossijskoj Federacii (VMedA), patentoobladatel'. Sposob hirurgicheskogo lechenija protjazhennyh striktur mochetochnika. Patent RF \# 2625782. 14.06.2016. Russian.
Каприн А. Д. Использование буккального графта при стриктурах мочеточника. Урология. 2018; 1: 138-142. DOI: 10.18565/urology. 2018.1.138-142.

11. Kranz J, Brandt AS, Anheuser P, Reisch B, Steffens J, Roth S. Radiogene Harnleiterstrikturen: Mögliche Therapieoptionen [Ureteral stricture as a late complication of radiotherapy: Possible treatment options]. Urologe A. 2017; 56 (3): 322-28. DOl: 10.1007/s00120-016-0294-z.

12. Ganpule AP, Singh AG, Islam MR, Sonawane P, Sabnis RB, Desai MR. Robotic buccal mucosa graft ureteroplasty (inlay and onlay) for upper ureteric stricture: Point of technique. J Minim Access Surg. 2018; 14 (4): 357-61. DOI: 10.4103/jmas.JMAS_188_17.

13. Lee Z, Keehn AY, Sterling ME, Metro MJ, Eun DD. A Review of Buccal Mucosa Graft Ureteroplasty. Curr Urol Rep. 2018; 19 (4): 23. DOI: $10.1007 /$ s11934-018-0772-5.

14. Волков А. А., Зубань О. Н., Будник Н. В., Саенко Г. И. Использование комбинированного буккально-лабиального лоскута в хирургическом лечении протяженных стриктур и облитераций верхней трети и лоханочно-мочеточникового сегмента. Хирург. 2019; 10: 58-67. DOI: 10.33920/med-151910-05.

15. Kroepfl D, Loewen H, Klevecka V, Musch M. Treatment of long ureteric strictures with buccal mucosal grafts. BJU Int. 2010; 105(10): 1452-1455. DOI: 10.1111/j.1464-410X.2009.08994.x.

16. Синельников Л. М., Протощак В. В., Карпущенко Е. Г., Бабкин П. А., Паронников М. В., Кислицын П.О., авторы; Федеральное государственное бюджетное военное образовательное учреждение высшего образования «Военно-медицинская академия имени С.М. Кирова» Министерства обороны Российской Федерации (ВМедА), патентообладатель. Способ лечения протяженных стриктур тазового отдела мочеточника с использованием аутотрансплантата из слизистой щеки. Патент РФ № 2712863. 01.07.2019.

17. Волков А. А., Зубань О. Н., Будник Н. В., авторы. Волков А. А., патентообладатель. Способ хирургического лечения рецидивных и постлучевых протяженных стриктур и облитераций нижней трети мочеточника. Патент РФ № 
2709167. 11.04.2019.

18. Hefermehl LJ, Tritschler S, Kretschmer A, Beck V, Stief CG, Schlenker B, et al. Open ureteroplasty with buccal mucosa graft for long proximal strictures: A good option for a rare problem. Investig Clin Urol. 2020; 61 (3): 316-22. DOI: 10.4111/icu.2020.61.3.316.

19. Nishimura Y, Moriya K, Nakamura M, Kitta T, Kanno Y, Chiba H, et al. Laparoscopic ureterocalicostomy for ureteropelvic junction obstruction in a 10-year-old female patient: a case report. BMC Res Notes. 2017; 10 (1): 247. DOI: 10.1186/s13104-017-2569-x.

20. Gong H, Lu Y, Yan Y, Wu Z, Gao W, Cheng H, et al. Laparoscopic Extravesical Submucosal Tunneling Ureteroneocystostomy Combined with Psoas Hitch for Medium-Length Distal Ureteral Defects in Adults. Urol Int. 2017; 98 (3): 343-49. DOI: 10.1159/000454735.

21. Manassero F, Mogorovich A, Fiorini G, Di Paola G, De Maria M, Selli C. Ureteral reimplantation with psoas bladder hitch in adults: a contemporary series with long-term followup. Scientific World Journal. 2012; 2012: 379316. DOI: 10.1100/2012/379316.

22. Castilló-Vela I, Del Pozo Jiménez G, Turo Antona J, Vázquez Alba D, Sáenz Medina J, Carballido Rodríguez J. Reimplante ureteral laparoscópico con Flap de Boari [Laparoscopic Boari Flap ureteral reimplantation.]. Arch Esp Urol. 2017; 70 (4): 436-44.

23. Комяков Б. К., Гулиев Б. Г. Хирургия протяженных сужений мочеточников. СПб.: Невский диалект, 2005; 257 с.

24. Schott F, Becker B, Gross AJ, Netsch C. Symptomatic Distal Ureteral Stone in an lleal Ureter: Treatment by Combined Supine Ureteroscopy and Mini Percutaneous Nephrolithotomy. J Endourol Case Rep. 2017; 3 (1): 90-92. DOI: 10.1089/cren.2017.0049.

25. Kocot $A$, Kalogirou $C$, Vergho D, Riedmiller $H$. Long-term results of ileal ureteric replacement: a 25 -year single-centre experience. BJU Int. 2017; 120 (2): 273-279. DOI: 10.1111/bju.13825.

26. Fallon B., Gaynor-Drupnick DM. Adult ureteral reconstruction. Urol Board Rev Manual. 2004; 12 (30): 2-11.

27. Tran $\mathrm{H}$, Arsovska O, Paterson RF, Chew BH. Evaluation of risk factors and treatment options in patients with ureteral stricture disease at a single institution. Can Urol Assoc J. 2015; 9 (11-12): E921-E924. DOI: 10.5489/cuaj.3057.

28. Xiong S, Wang J, Zhu W, Yang K, Ding G, Li X, et al. Onlay Repair Technique for the Management of Ureteral Strictures: A Comprehensive Review. Biomed Res Int. 2020; 2020: 6178286. DOI: 10.1155/2020/6178286.

29. Del Pozo Jiménez G, Castillón-Vela I, Carballido Rodríguez J. Uso de injerto de mucosa oral en el tratamiento de estenosis ureterales extensas: revisión de conjunto [Buccal mucosa graft for the treatment of long ureteral stenosis: Bibliographic review.]. Arch Esp Urol. 2017; 70 (4): 445-53.

30. Fahmy O, Schubert T, Khairul-Asri MG, Stenzl A, Gakis G. Total proximal ureter substitution using buccal mucosa. Int J Urol. 2017; 24 (4): 320-23. DOI: 10.1111/iju.13307.

31. Паронников М. В., Шестаев А. Ю., Карпущенко Е.Г., Синельников Л. М., Протощак В. В., Янцев А. А. авторы; Федеральное государственное бюджетное военное образовательное учреждение высшего образования «Военно-медицинская академия имени С.М. Кирова» Министерства обороны Российской Федерации (ВМедА), патентообладатель. Способ хирургического лечения протяженных стриктур мочеточника. Патент РФ № 2625782. 14.06.2016. 